\title{
Decision Support System for Selecting University in Pekanbaru Based on Android
}

\author{
Dewi Nasien* \\ Department of Information Technology \\ Universitas Riau \\ Pekanbaru, Indonesia \\ dewi.nasien@lecturer.unri.ac.id \\ Gilang Rianda \\ Department of Information Technology \\ Universitas Riau \\ Pekanbaru, Indonesia \\ gilang.rianda5987@student.unri.ac.id
}

\author{
Ahmad Mulyadi \\ Department of Information Technology \\ Universitas Riau \\ Pekanbaru, Indonesia \\ ahmad.mulyadi1863@student.unri.ac.id \\ Deni Yulianti \\ Department of Computer Science \\ Universiti Teknologi Malaysia \\ Johor, Malaysia \\ deniyulianti@gmail.com
}

\author{
Ahmad Sukabul \\ Department of Information Technology \\ Universitas Riau \\ Pekanbaru, Indonesia \\ ahmad.sukabul3336@student.unri.ac.id \\ M. Hasmil Adiya \\ Department of Computer Science \\ Institut Bisnis dan Teknologi \\ Pelita Indonesia \\ Pekanbaru, Indonesia \\ hasmil.adiya@lecturer.pelitaindonesia.ac.id
}

*corresponding author: Dewi Nasien, dewinasien@lecturer.pelitaindonesia.ac.id

\begin{abstract}
Nowadays development of technology is growing fast, especially Android Operating System (OS). Android is a technology that can help humans to improve their works, both quality and quantity, e.g., making decisions. This study discusses the application of decision support systems to select a university. Many students are still confused to select the best university for them. Hence, this application aims to assist students in making decisions using a weighted product (WP) method. It exploits some criteria, namely, Distance, university accreditation, and a number of lecturers. The research methodology is used, namely problem analysis, analysis of both hardware and software requirements, design system, implementation, and testing. Ultimately, the application can be utilized. This application is built on Android Studio and Java Development Kit. It is implemented in Universities in Riau. This application can help students to choose the best university quickly and accurately.
\end{abstract}

Keywords-Decision Support System, Weighted Product, Selection of Universities, Android

\section{INTRODUCTION}

Currently, many universities offer majors by comparing their strengths to each other. Therefore, it makes students confusing to choose. Hence, it needs a system to make it easier to select a university by comparing the quality of universities that can be utilized on the Android Operating System (OS). Android is a Linux kernel-based used on smartphones and tablet computers. Android is a complete platform consisting of an operating system, application, and development tools. It is supported by various open source communities in the world. Consequently, it makes Android growing fast and able to develop in terms of devices and technology [1]. Android Studio is an Integrated Development Environment (IDE), an official software to make Android applications. It is based on IntelliJ IDEA. The development of IntelliJ is located in a code editor and providing more features. Ultimately, it can increase making Android applications [2].

The concept of Decision Support Systems (DSS) is needed in supporting stages for making a decision. It starts with identifying problems, data selection, approach selection, and evaluating such an approach [3]. The main objective is to help in making decisions, both structured and semi-structured issues [4]. Characteristic of DSS consists of five [5], namely, divide problems into semi-structured or unstructured; combine analytical methods, conventional data, data search, and information integration; use an interactive model (user friendly) and flexible and able to adapt in any environments. Another strengths of DSS [5] are to extend user capabilities, save time for solving problems, especially for complex issues; problem solution is more reliable; produce another alternative solution and can find additional evidence to increase justification.

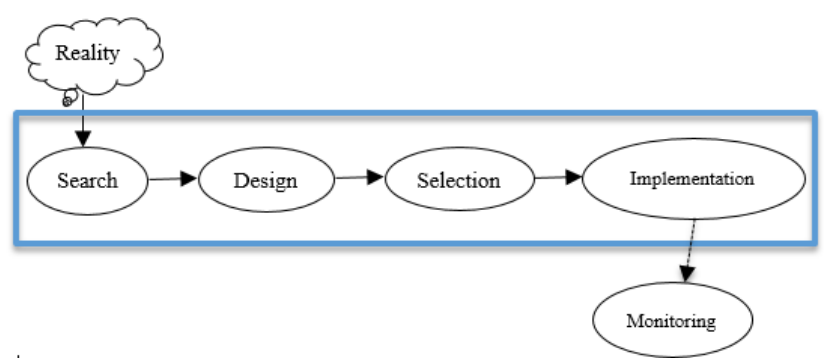

Fig. 1. Framework of DSS

There are four stages in DSS [6] as shown in Figure 1. Firstly, search (intelligence), a process of searching and detecting elements that cause problems. Secondly, design is a process to make several methods that can be a problem solution. Thirdly, selection (choice) is selection of an alternative model that can solve a problem. Fourthly, implementation is to apply the chosen method into a system using a computer. Fifthly, monitoring is a process to know 
the function as expected.

After students complete high school education level, the student wants to proceed to the university that is in accordance with the student's ideas and expertise. To determine the best university, students need a decision. This research makes a selection process to choose the university using Weighted Product (WP) method. The selection of WP because it's easy to calculate compared to other methods. The research problem is how to make a decision to choose the right university using WP method.

This paper is arranged as follows: Section 2 describes the literature review. Section 3, explains the research methodology. Result can be seen in Section 4. Finally, Section 5 draws a conclusion from DSS for selecting a university.

\section{LITERATURE REVIEW}

The system is a collection of interrelated elements that are responsible for processing input so as to produce output. The system is a network of interrelated procedures, gathered together to complete a particular goal [7]. Android is a Linux-based mobile operating system that includes operating systems, middleware and applications. Android provides an open platform for developers to create applications for smartphones. Initial release of Android was on November $5^{\text {th }}, 2007$. Android Studio is an official Integrated Development Environment (IDE) for the development of Android applications. It is open source. The launch of Android Studio was on May $16^{\text {th }}, 2013$, by Google. Consequently, Android Studio has replaced Eclipse as an official IDE. Figure 2 shows Android Studio logo [2].

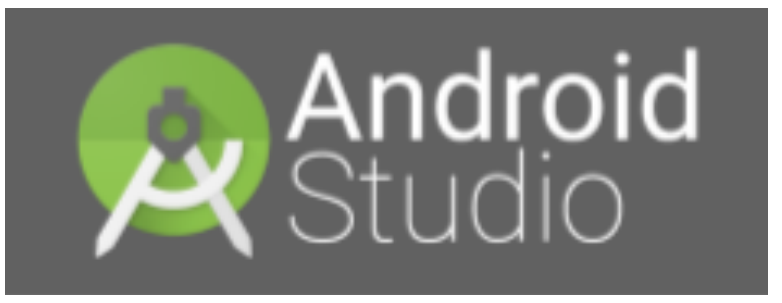

Fig. 2. Android Studio

Java Development Kit (JDK) is a set of software to develop Javabased software. Meanwhile, Java Runtime Environment (JRE) is the implementation of Java Virtual Machine (JVM) that is used to run java programs. Each JDK contains one or more JREs and various other development tools, i.e., java compiler sources, bundling, debuggers, and development libraries [2].

According to in [9], decision support systems are interactive information systems that provide information, modeling

and data manipulation to help to make decisions in structured and unstructured situations. One of the methods of DSS is the weighted product. The weighted product method is a multi-criteria decision analysis in terms of a number of decision criteria. Each decision alternative is compared with the others by multiplying the number of ratios, one for each decision criterion.

The research about DSS using a weighted product is already explored by researchers. But, the study still explored by researchers until today. For instance, Niswatin proposed the WP method in 2016 to select new student admission [8]. Criteria used are the results of the final exam and test for subjects are Mathematical, Indonesian language, and the English language - the result of this research that can help the selection process new student at Nusantara University PGRI Kediri. In a study conducted by Oktavina et al., 2015, applied WP to determine the best customers at TB. Bangun Jaya [10]. The proposed weighted product method is to choose appropriate customers to get bonuses based on customer's invoices and ratings from the store. It implements MySQL as a database system and PHP programming language. Next, in [11] proposed WP method to promote employee contracts into permanent employees through several selection criteria, namely: discipline, work experience, insight, teamwork, behavior, loyalty, and responsibility. In [12], it proposed WP method in determination of the best private universities, especially majoring computer. In determining the quality of higher education, there are several criteria are number of computer science, tuition, campus environment, the number of scholarship programs, and accreditation BAN PT. It applied using the website.

\section{MethodOLOGY}

In this section describes the methodology used in this research. It starts with identification of problem, analysis, design, coding, and testing. In the first part, the problem of identification refers to what issues need to be known before starting the research. What criteria are students looking for in choosing a University. This research only focus on three private universities in Pekanbaru, namely ST Manajemen Ilmu Komputer Amik Riau, ST Ilmu Farmasi Riau, and ST Ilmu Ekonomi Riau. There are three criteria that become parameters of this WP method, namely Distance, accreditation from a university, and the number of lecturers. Next, analysis is the most important part because this section will analyze the results that have been obtained from the first stage. In this section, explain what inputs are needed, what will be done on the WP method (weighting improvements, $\mathrm{S}$ and $\mathrm{V}$ matrix calculations), and finally, the ranking calculation by looking at the highest value in choosing a University. Then, hardware and software requirements are determined. Then, the process of design. At this stage, create a Graphical User Interface (GUI) that will be applied to the android application. At the coding stage, all information that has been obtained is applied in the Java programming language using android studio software. Finally, testing. The test referred to here is testing the system and analyzing the accuracy of the WP method in determining private universities in Pekanbaru.

\section{RESUlts}

\section{A. Calculation Weighted Product}

The location of the testing point is located at Jl. Sudirman in Pekanbaru, Riau (Back of Awal Bros Hospital). There are some criteria utilized, namely, Distance, accreditation and number of lecturers. The calculation uses Weighted Product (WP) method. It also uses Hill Cipher to determine parameter that can be used as a reference for making a decision. There are three (3) parameters; namely, $\mathrm{Cl}=$ Distance, is length range from residence to university in kilometers (KM); $\mathrm{C} 2=$ Accreditation, is the value of university-based on quality and C3 = Number of lecturers, is total lecturers in a university. Table 1 shows value of weight for each criteria namely, Distance, accreditation and number of lectures. The weight value of both university accreditation and number of lecturers in university are 4. University accreditation and number of lecturers are the highest priority to determine the best university to be selected. Next, Distance is the lowest priority with value is 2 . Weight value is symbolized as $\mathrm{W}$.

Table 2 reflects weight value of university accreditation. It defines quality of university. If weight value is A, meaning the university has a very good quality. While, if weight value is $\mathrm{B}$, meaning the university has a good quality. Meanwhile, if weight value is $\mathrm{C}$, meaning the university has a quite good quality. Lastly, if weight value is NB, meaning university 
accreditation is still on-going process.

TABLE I. WEIGHT VALUE OF EACH CRITERION

\begin{tabular}{|c|c|c|}
\hline Criteria & Name Criteria & $\begin{array}{c}\text { Weight Value } \\
\text { (W) }\end{array}$ \\
\hline C1 & Distance & 2 \\
\hline C2 & Accreditation & 4 \\
\hline C3 & Number of lecturers & 4 \\
\hline
\end{tabular}

TABLE II. ACCREDITATION OF UNIVERSITIES

\begin{tabular}{|c|c|c|}
\hline \multirow{2}{*}{ Criteria } & $\begin{array}{c}\text { Accreditation } \\
\text { Criteria }\end{array}$ & Weight Value (W) \\
\hline \multirow{4}{*}{ Accreditation } & NB & 1 \\
\cline { 2 - 3 } & $\mathrm{C}$ & 2 \\
\cline { 2 - 3 } & $\mathrm{B}$ & 3 \\
\cline { 2 - 3 } & $\mathrm{A}$ & 4 \\
\hline
\end{tabular}

Table 3 represents range number of lecturers in university. It comprises 5 groups namely, 0-10 people, 11-20 people, 21-30 people, $30-40$ people and more than 40 people.

TABLE III. NUMBER OF LECTURERS AT UNIVERSITIES

\begin{tabular}{|c|c|c|}
\hline Criteria & $\begin{array}{c}\text { Criteria Range Number } \\
\text { of Lecturers }\end{array}$ & $\begin{array}{c}\text { Weight Value } \\
\text { (W) }\end{array}$ \\
\hline \multirow{4}{*}{$\begin{array}{c}\text { Number of } \\
\text { Lecturers }\end{array}$} & $0-10$ & 1 \\
\cline { 2 - 3 } & $11-20$ & 2 \\
\cline { 2 - 3 } & $21-30$ & 3 \\
\cline { 2 - 3 } & $30-40$ & 4 \\
\hline
\end{tabular}

Table 4 indicates that there are 3 universities as an alternative choice that wants to be enrolled as input into the system.

TABLE IV. ALTERnATIVES USED

\begin{tabular}{|c|c|}
\hline Alternative & Name of Universities \\
\hline A1 & ST Manajemen Ilmu Komputer Amik Riau \\
\hline A2 & ST Ilmu Farmasi Riau \\
\hline A3 & ST Ilmu Ekonomi Riau \\
\hline
\end{tabular}

Furthermore, a data search can be conducted for the above universities with a starting point at Jl. Jendral Sudirman, in Pekanbaru, Riau (Back of Awal Bros Hospital).

a. ST Manajemen Ilmu Komputer AMIK Riau

The Distance from residence to the university is $13 \mathrm{~km}$, university accreditation is $\mathrm{B}$, and a number of lecturers are 38 people.

b. ST Ilmu Farmasi Riau

The Distance from residence to the university is $14 \mathrm{~km}$, and university accreditation is $\mathrm{B}$, and a number of lecturers are 20 people.

c. ST Ilmu Ekonomi Riau

The Distance from residence to the university is $12 \mathrm{~km}$, university accreditation is $\mathrm{C}$, and a number of lecturers are 44 people.

After the data has been obtained, input such data into a table to be exploited as a reference. Table 5 shows Alternative Matches. It consists of 3 criteria, namely, C1, C2, and C3. C1 defines Distance, $\mathrm{C} 2$ indicates university accreditation, and $\mathrm{C} 3$ indicates a number of lecturers. Meanwhile, it comprises 3 universities, which are A1, A2, and A3. A1 describes ST Manajemen Ilmu Komputer AMIK Riau, A2 represents ST Ilmu Farmasi Riau, and A3 shows ST Ilmu Ekonomi Riau.
TABLE V. ALternAtive MATChES

\begin{tabular}{|c|c|c|c|}
\hline \multirow{2}{*}{ Alternative } & \multicolumn{3}{|c|}{ Criteria } \\
\cline { 2 - 4 } & C1 & C2 & C3 \\
\hline A1 & $13 \mathrm{~km}$ & 3 & 4 \\
\hline A2 & $14 \mathrm{~km}$ & 3 & 3 \\
\hline A3 & $12 \mathrm{~km}$ & 2 & 5 \\
\hline
\end{tabular}

After matching the values of each criterion. Then, the next step is repair of weight first, where the initial weight $W=(2,4,4)$ to be fixed to $W_{J}=\frac{W_{j}}{\sum W_{j}}$, where:

$$
\begin{array}{ll}
W_{j} & =\text { Weight value } \\
\Sigma W_{j} & =\text { Number of weight values }
\end{array}
$$

and obtained values of $W 1, W 2, W 3$ as follows:
a) $\quad W_{1}=\frac{2}{2+4+4}=0,2$
b) $W_{J}=\frac{4}{2+4+4}=0,4$
c) $\quad W_{J}=\frac{4}{2+4+4}=0,4$

After making improvements, the next step is to calculate the $\mathrm{S}$ vector value, using multiplication to link the attribute rank. Rating attributes must be increased first with the weight of these attributes. The formula of vector $\mathrm{S}$ is:

$$
S_{\mathrm{i}}=\prod_{J=1}^{n} X_{i j}^{W_{J}}
$$

with $\mathrm{i}=1,2,3, \ldots, \mathrm{n}$. where $\mathrm{j}=1, \mathrm{Wj}$ is rank positive for benefit attribute $(\mathrm{C} 2$ and $\mathrm{C} 3)$ and negative value $(\mathrm{C} 1)$ for cost attribute.
a) $\quad S 1=\left(13^{(-0,2)}\right)\left(3^{0,4}\right)\left(4^{0,4}\right)=1,62$
b) $S 2=\left(14^{(-0,2)}\right)\left(3^{0,4}\right)\left(3^{0,4}\right)=1,42$
c) $\quad S 3=\left(12^{(-0,2)}\right)\left(2^{0,4}\right)\left(5^{0,4}\right)=1,53$

After obtaining the $\mathrm{S}$ vector value in each of the next alternatives is to rank to determine the best alternative choice. This ranking uses the value $V$ where the formula of $V$ is:

$\begin{array}{lll} & V_{\mathrm{i}}=\frac{\prod_{J=1}^{n} X_{i j w j}}{\prod_{J=1}^{n}\left(X_{i j} * w j\right.} \\ & =1,2,3, \ldots, \mathrm{n} \\ I & = & \text { Alternative preferences are analogous to } \\ V & = & \text { vectors } \\ V \mathbf{x} & = & \text { Weight of criteria / sub criteria } \\ W & = & \text { Alternative } \\ i & = & \text { Criteria } \\ j & = & \text { Number of criteria } \\ n & = & \text { The number of criteria that have been } \\ * & & \text { assessed in vector S }\end{array}$

Or more simply as:

where:

$$
V_{\mathrm{i}}=\frac{S_{i}}{\sum s_{i}}
$$

$\begin{array}{ll}I & = \\ V & =\begin{array}{l}\text { Alternative preferences are analogous to } \\ \text { vectors }\end{array}\end{array}$

tons




$$
\begin{array}{ccc}
S_{i} & = & \text { Vector } \mathrm{S} \\
\sum S_{i} & = & \\
& \text { Number of Vector } \mathrm{S}
\end{array}
$$

Then, calculate values of $V 1, V 2$ and $V 3$ as follow:

a) $V 1=\frac{1,617591}{1,617591+1,4205283+1,52825952}$

$$
=\frac{1,617591}{4,5663788}=\mathbf{0 . 3 5}
$$

b) $V 2=\frac{1,4205283}{1,617591+1,4205283+1,52825952}$

$$
=\frac{1,4205283}{4,5663788}=\mathbf{0 . 3 1}
$$

c) $V 3=\frac{1,5282595}{1,617591+1,4205283+1,52825952}$

$$
=\frac{1,5282595}{4,5663788}=\mathbf{0 . 3 3}
$$

Based on the calculation, $V 1$ has a higher value than the values $V 2$ and $V 3$.

\section{B. Implementation}

Figure 3 shows the user guide to use the application. This page is displayed once the application is operated. It describes weighting criteria consisting of Distance, accreditation, and number of lecturers. Button "NEXT" is used to go to the next page.

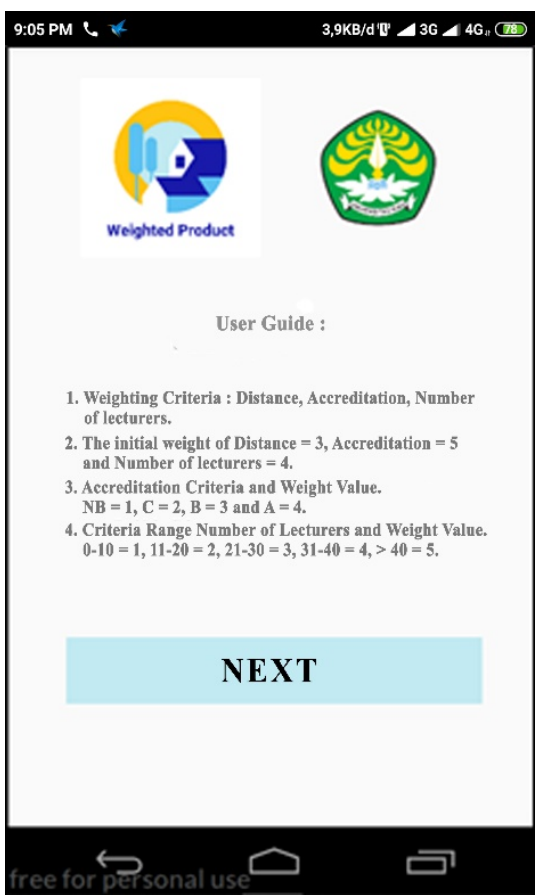

Fig. 3. User Guide Page

Figure 4 describes input page 1, namely, Alternative 1. This stage is to fill data on Alternative Pages 1. Data is filled using name of university. Further, it is followed by Distance from user's residence to the university, weight value of university accreditation, and weight value of a number of lecturers. If the data has been filled, then press "NEXT" button.

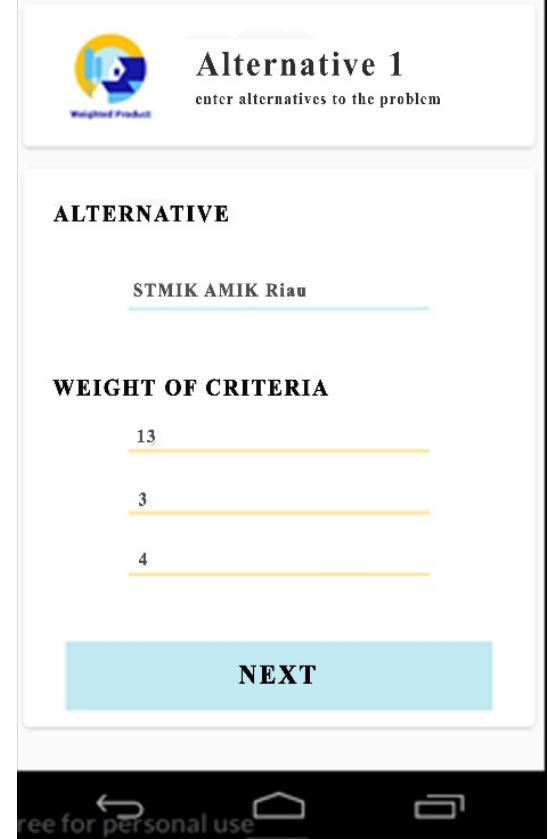

Fig. 4. Input Page 1

The second input page is the same way as the input page 1 . Figure 5 shows the input page 2 .

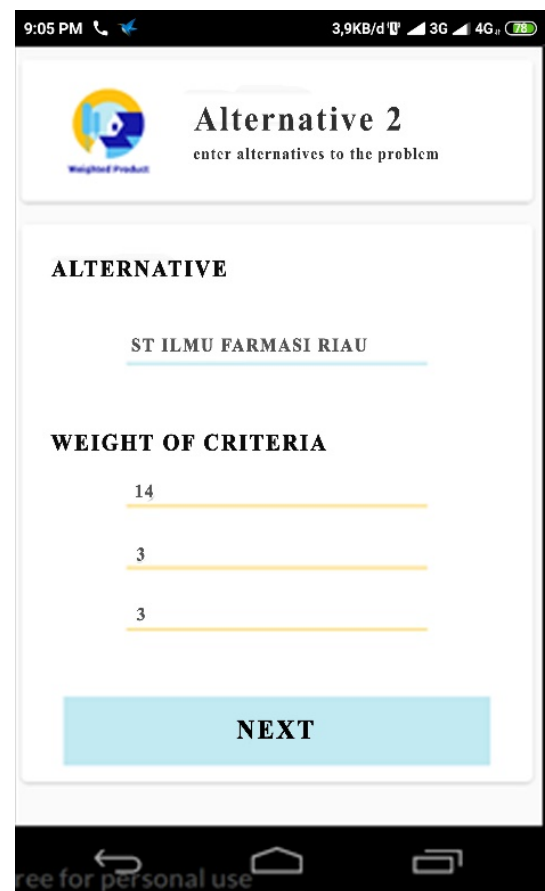

Fig. 5. Input Page 2

The third input page has the same input method as the previous page. Figure 6 shows the input page 3 . 


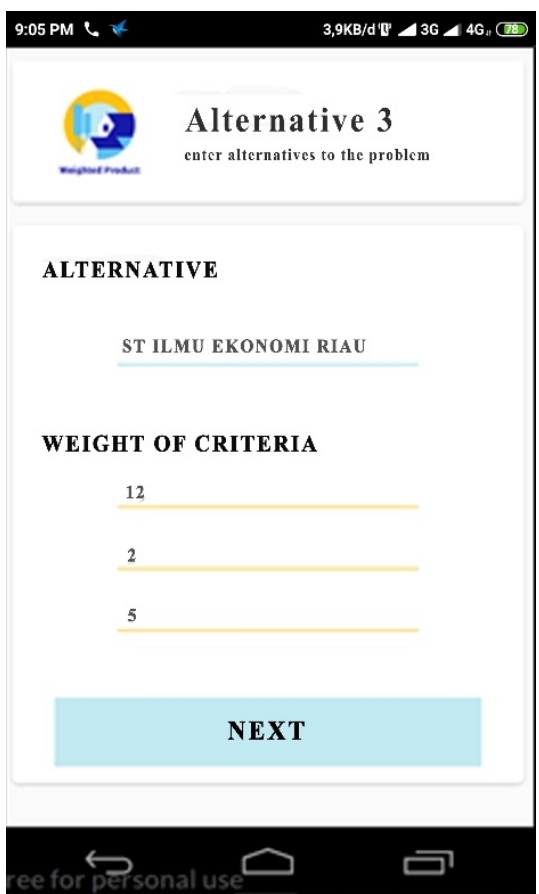

Fig. 6. Input Page 3

Therefore Figure 4, Figure 5 and Figure 6 represent three (3) name of universities as choices that is filled by user. User can input three (3) universities that wants to be registered.

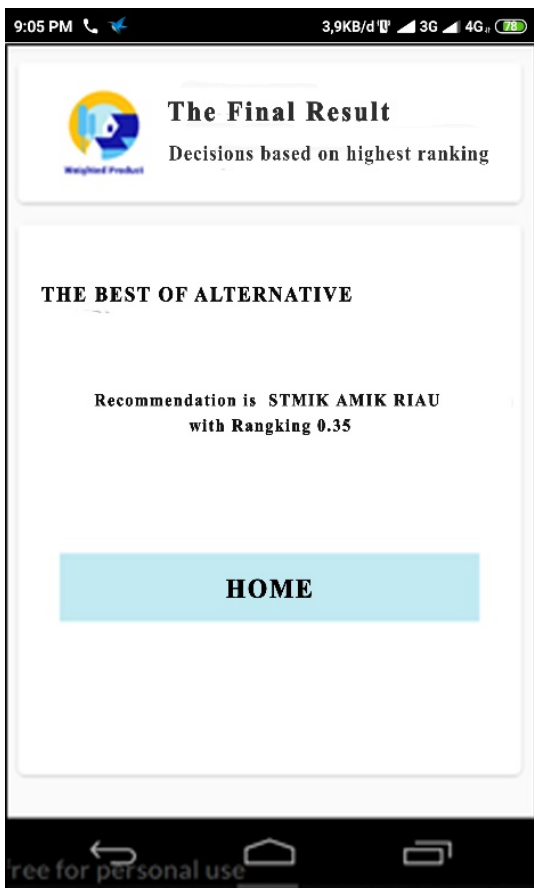

Fig. 7. DSS Result

Figure 7 shows the best alternative result using WP method as DSS. The system chooses the appropriate university to user. From three (3) universities namely, STMIK AMIK Riau, ST Ilmu Farmasi Riau and ST Ilmu Ekonomi Riau. The recommendation university is STMIK AMIK RIAU with ranking value 0.35.

\section{CONCLUSION}

Based on experimental results, there are some conclusions that can be described. First, the application uses WP method as calculation process so it is more accurate. However, decision making is depend on users. Secondly, it can help users making decision to select appropriate university. Thirdly, the application is utilized in Pekanbaru area. Finally, the application is based on Android OS and it can be exploited in everywhere and offline (without Internet connection).

\section{REFERENCES}

[1] Noer, Z. M., \& Ngamali, K, “Aplikasi Perpustakaan SMK Siliwangi AMS Banjarsari Berbasis Android". Jurnal Manajemen Informatika (JUMIKA), 4(2). 41-50, 2017.

[2] Android Developers, Meet Android Studio, https://developer.android.com, [Online] Available: https://developer.android.com/studio/intro, Accessed: 20-Sep-2019.

[3] Averweg, U. R, "Historical Overview of Decision Support Systems (DSS)", In Encyclopedia of Information Science and Technology, Second Edition (pp. 1753-1758). IGI Global, 2009.

[4] VanSchaik, F. D., \& Sol, H. G, Effectiveness of decision support systems. In Twenty-Third Annual Hawaii International Conference on System Sciences (Vol. 3, pp. 50-58). IEEE, 1990.

[5] Turban, E., Liang, T. P., \& Aronson, J. E, "Decision Support Systems and Intelligent Systems", International Edition, Pearson Prentice Hall, 2005.

[6] Simon, H. A, "The new science of management decision", 3rd revised edition, Prentice-Hall, Englewood Cliffs, New York, 1960

[7] Manik, A. R. S, "Penerapan Metode Weighted Product Dalam Sistem Pendukung Keputusan Seleksi Penerimaan Beras Untuk Masyarakat Miskin”, Jurnal Teknik Informatika Universitas Dian Nuswantoro, 1 (3), pp. 31-36, 2016.

[8] Niswatin, R. K, "Sistem Seleksi Penerimaan Mahasiswa Baru Menggunakan Metode Weighted Product (WP)", SEMNASTEKNOMEDIA online, 4(1), 1-3, 2016.

[9] Kom, K. M, "Konsep dan Aplikasi Sistem Pendukun Keputusan”, Yogyakarta: CV Andi Offset, 2007.

[10] Oktavina, R., \& Himawan, H, "Sistem Pendukung Keputusan Untuk Menentukan Pelanggan Terbaik Pada TB”, Bangun Jaya Menggunakan Metode Weighted Product (WP). 1-9, 2015.

[11] Lingke, D. Y. R., \& Kurnianto, H, "Decision Support Systems Recommendations for Employees Permanent Using Weighted Product. Jurnal SIFO Mikroskil, 18(1), 21-30, 2017.

[12] Solikhun, S, "Perbandingan Metode Weighted Product dan Weighted Sum Model dalam Pemilihan Perguruan Swasta Terbaik Jurusan Komputer” Klik-Kumpulan Jurnal Ilmu Komputer, 4(1), 70-87, 2017. 